Article

\title{
Looking for Black Religions in 20th Century Comics, 1931-1993
}

\section{Yvonne Chireau}

Department of Religion, Swarthmore College, Swarthmore, PA 19081, USA; ychirea1@swarthmore.edu

Received: 10 April 2019; Accepted: 12 June 2019; Published: 25 June 2019

\begin{abstract}
Relationships between religion and comics are generally unexplored in the academic literature. This article provides a brief history of Black religions in comic books, cartoons, animation, and newspaper strips, looking at African American Christianity, Islam, Africana (African diaspora) religions, and folk traditions such as Hoodoo and Conjure in the 20th century. Even though the treatment of Black religions in the comics was informed by stereotypical depictions of race and religion in United States (US) popular culture, African American comics creators contested these by offering alternatives in their treatment of Black religion themes.
\end{abstract}

Keywords: comics; black religions; Voodoo; Black Panther; race and religion; African American religions

Despite its acclaim as a unique vision of the genius of Africana cultures, the superhero comic book Black Panther (Figure 1) is not well known for its portrayals of religion. Nevertheless, over its 53-year history, the comic frequently referenced ancestral religious rituals, supernatural realms and landscapes, and theologies of divine kingship. ${ }^{1}$ Even though the relationships between religion and comics are largely unexamined, illustrations of black religions in comics are not new.

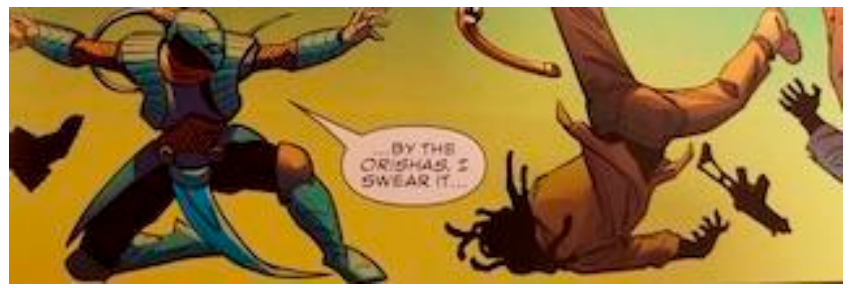

Figure 1. Orishas in Black Panther, 2016.

More than 150 years before the advent of Black Panther, a representation of Africana religions appeared in a British cartoon called Johnny Newcome in Love in the West Indies. In this 1808 sequential art print, the religious tradition known as obeah appeared in a story about the adventures of a hapless English plantation master in slavery-era Jamaica. In one panel, Newcome consults an "Oby man" to seduce "Mimbo Wampo", a slave woman. We see the black conjurer, with grizzled beard, staff, and medicine pot with feathers, grave dirt, and egg shells, dispensing assurances to Newcome, who is pictured in another scene with nine offspring from his liaison with Mimbo Wampo, now the "queen" of his "harem". The cartoon construed the spiritual tradition of obeah as a bizarre magical practice, while describing the perils of social intercourse between blacks and whites in the New World environment.

1 (Cowan 1988) See also (Faithful 2018); (Alexander 2018) and (Love n.d.). 
The wry commentary indicates that prior to the twentieth century, the perceived "otherness" of African-based traditions like obeah readily translated into fodder for satire in the comics medium. ${ }^{2}$

In this article, I discuss Africana (African diasporic) religions, Islam, Christianity, and black folk traditions such as Hoodoo and Conjure, as they appeared in 20th-century cartoons, animation, comic books, and comic strips. Although comics are a topic of current academic interest in literature, history, and cultural studies, few discussions give focused attention to black religions. This lapse occurs in analyses of comics that represent Africana spiritual practices, and in comics that promote religious stories in order to educate or proselytize. Charting black religions in 20th century comics opens a window onto views of race and religion during this period and provides insights into the use of negative stereotypes that denigrate and distort Africana spiritual traditions. A focus on black religions also affirms the ways that African American comics creators contested racial misrepresentations with viable portrayals of black spiritual life. ${ }^{3}$ In this article overview, I look at comics' treatments of black religions in two movements. Part one speaks to the impact of misrepresentation, stereotyping, and caricature in depictions of black religions, particularly in mainstream American comics in the early- to mid-20th century. Part two considers the work and influence of black comics artists, writers, and other creators of black subjects and their engagement with religious themes in the same period to the turn of the 21st century. I show that, in depicting black religions, comics both supported and contested representations of race and religion in ways that parallel and diverge from their actual historical presence in United States (US) popular culture.

\section{Representation from the Outside}

In the United States, issues of black representation were hard fought on the battlefields of popular culture, with comics at the forefront of many of those battles. As cultural artifacts, comics reflect many of the beliefs, values, and norms of the society in which they are produced. Insofar as African American religions are also products of culture, they are evaluated by society according to the prevailing ethnocentric standards of the majority. Nevertheless, due to their subordinate status, black religions are rarely represented on their own terms in the art and literature of popular culture. ${ }^{4}$ For example, in the heyday of comics' rise in the early 20th century, black religions inhabited a diverse continuum that was rarely seen in popular depictions. Churches, organized sects, folk traditions passed down from slavery, political-spiritual institutions, and house temples existed side by side in African American communities throughout the United States. ${ }^{5}$ Often categorizing black traditions in pejorative terms as imperfect cognates of white Protestant Christianity, the disdain of the dominant society for black religions was made apparent by the invention of "Voodoo" to denote black religions of Africa, the Caribbean, and their American siblings, the black folk traditions of Hoodoo and Conjure. Adopted wholesale by comics artists and writers, cultural formations of "Voodoo" worked to vilify black religions with stereotyped characters, images, and narratives. In the first half of the 20th century, comics would turn en masse to the use of stereotypes, a practice with profoundly negative implications. ${ }^{6}$

As a "medium of extremes", according to comics scholar Fredrik Stromberg, comics utilize stereotypes to simplify subjects in order to generate meaning, reducing physical characteristics with a visual shorthand of basic, recognizable symbols, and imagery. ${ }^{7}$ The early, widespread stereotyping of

2 Early comic images of black religion by African Americans are rare, although future research might illuminate the contributions of 19th century black artists and cartoonists such as Patrick Henry Reason and Henry Jackson Lewis, who provided illustrations in early African American newspapers and publications on a number of topics. See (Cutter 2017); (Taylor 2014) and (Jackson 2016, pp. 12-15).

3 Academic studies of comics and religion include (Lewis and Kraemer 2010) and (Lewis and Lund 2017).

4 On the 20th century anti-comics cultural crusades see (Nyberg 1998); (Hajdu 2008); (Inge 1979); (Nelson 2013).

5 On African American religious pluralism see (Weisenfeld 2018); (Perez 2015); (Finley and Guillory 2015) and (Curtis and Sigler 2009).

6 On comics and racial stereotypes, see (Singer 2002); see also (Gordon 1998); (White and Fuentez 1997).

7 (Stromberg 2003, p. 29). 
black religions in cartoons and comics animation was accomplished by distilling certain representational elements of African American religiosity for comedic effect. For example, between 1930 and 1950, the "golden era" of cartooning in the US, black religion was mined for its entertainment value as animators created unambiguous reproductions of 19th century blackface minstrelsy and a host of profane caricatures of the most distinct qualities of black sacred life.

Black religious styles were consistently lampooned, as seen with the biblical satire Goin' to Heaven on a Mule (1934), the Merrie Melodies animated parody Clean Pastures (1937) (Figure 2) and the Walter Lantz supernatural ghost comedy A Haunting we Will Go (1939), as well as Lantz's jazz-inflected Voodoo in Harlem (1938) and Hanna-Barbera's Swing Social (1940), a cartoon musical whose rendering of black religion pitted the black church against the temptations of the "Voodoo devil" in a contest with a jitterbug choir and African-styled tom-toms. Black faith was also featured in cartoons that both imitated and ridiculed its expressions, such as the propensity for unrestrained emotionalism in worship, rhythmic music, and collective ritual practices for manifesting the Spirit with physical embodiment. Despite the institution of a production code for filmmakers in 1930 that prohibited "blasphemy, religious offense, and the ridicule of clergy", black preachers and religious authorities were regularly "burlesqued" according to cartoon historian Henry T. Sampson, while "priests, rabbis, or leaders of any other religious groups" were not. ${ }^{8}$

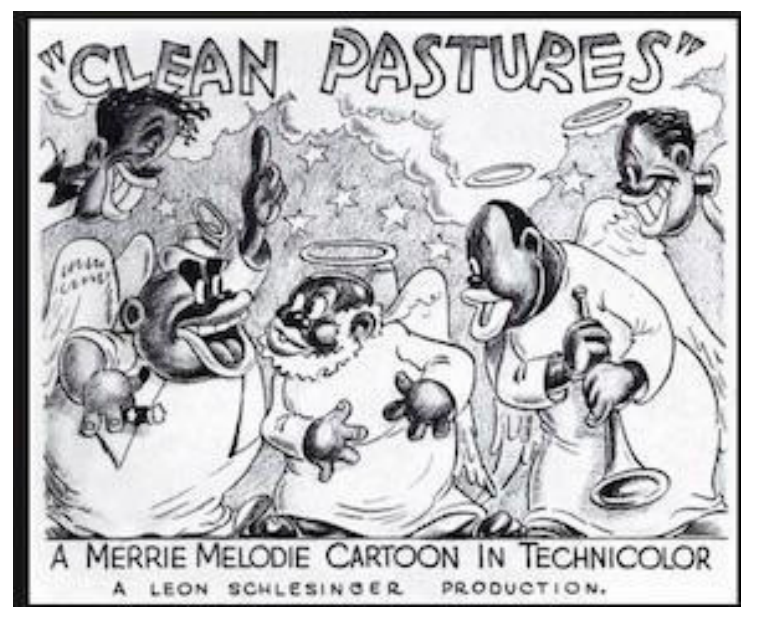

Figure 2. Black religion caricatures, Clean Pastures cartoon, 1937.

Animation creators utilized racial hyperbole in depicting black religious practices and beliefs. For example, animated comics with traditional African American worship practices tended toward the egregious use of "Negro" dialect, frenzied dancing and singing routines, pedantic storylines, indistinguishable subhuman characters, and the creation of "moral cartoons" which blended minstrel styles and religious lessons with clownish sermonizing. Derogatory representations also extended to print "funnies" in the 1930s and 1940s, with cartoon comics like Lil Eight Ball and Carl Bark's Donald Duck Hoodoo Voodoo, which maligned black spirituality as retrograde superstition, replete with blackface coons and pickaninnies whose terrified antics and exaggerated fears of ghosts provided the point for sight gags. (Figure 3) Viewed through the lens of American popular culture in the early 20th century, comics were indelibly linked to appropriations of black religion in a pernicious cycle of love and theft-or what Christopher Lehman calls "ignorance and contempt", as cherished traditions were subject to mockery and human characters depicted as ugly and disfigured, even as they were sensationalized as crowd-pleasing sources of entertainment. ${ }^{9}$

8 (Sampson 1998, p. 4); (Lehman 2007, pp. 39-45) and (Sammond 2015).

9 (Lehman 2007, p. 112). 


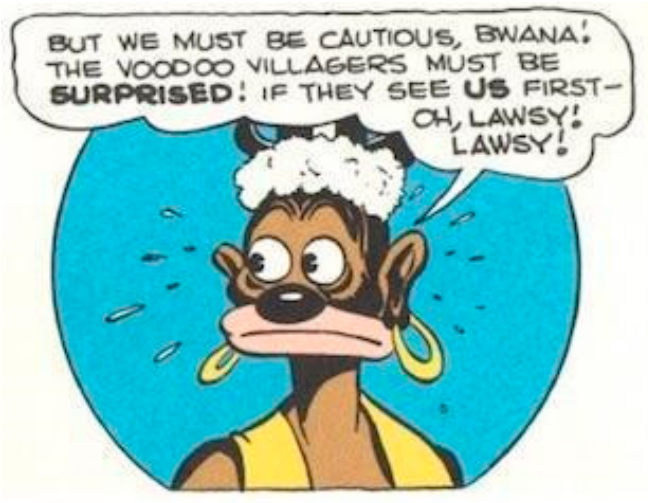

Figure 3. Blackface in Donald Duck Voodoo Hoodoo (1949).

Proceeding from post-Emancipation black cultures in the South, the folk religions associated with the poor and illiterate classes of rural African Americans were perceived as theologically undeveloped and backward by their urban and Northern peers. However, predominantly white comics artists and animators viewed folk traditions as "authentic" black religiosity and normalized their display as spectacle. Accordingly, black churches advanced a politics of respectability and racial progress that scorned negative associations between their faith practices and what they considered to be primitive spirituality. While black churches criticized unseemly aspects of black folk religion as ignorant heathenism, they also protested the commodification of African American sacred cultures, joining black leaders and the black press in condemning the use of racial stereotypes in comics, cartoons, and animation. They were divided, however, over the social problem of controversial Hoodoo and Conjure folk practices, magic traditions which were associated with "Africanisms" and iterations of what was commonly called Voodoo. ${ }^{10}$

Pluralism and heterogeneity were defining traits of black religion in the US from its very beginnings, and spiritual diversity remains an accepted part of the culture, historically strengthening the racial solidarity and inclusiveness of black communities. However, prior to the 1960s, Africana or black diaspora religions such as obeah, Santeria, and Vodou were viewed by most Americans as exotic and strange, with foreign gods, foreign practices, hailing from foreign places. Negative perceptions of these Africana traditions entered into portrayals of black religions in the comics at an early point. I use the phrase graphic Voodoo to refer to the ongoing characterization of Africana religions as insurgent and racialized, overdetermined by associations with sorcery, and presumed to be violent and dangerous. It is important to underscore that these discursive formations were inventions, wholesale fabrications, with little to do with actual religions and historical practices. Graphic Voodoo became a signifier for spiritual alterity that marked black "otherness" with resonant elements that disfigured two historical religious sources: indigenous African sacred traditions and Haitian Vodou. As a metonym for Africana religions, graphic Voodoo became a stand-in for race and religion as presented in many widely circulating comic books in the US, especially those of the action-adventure and horror genres. ${ }^{11}$

The aesthetics of graphic Voodoo, as first established in action-adventure jungle comics, depicted Africana spiritualities as uncivilized and idolatrous, but strangely powerful and compelling. Outlandish pictures of black religious authorities in roles as Voodoo priests and witch doctors-half-naked, with

10 On migration-era disputes over race and religion between black churches and the black press, see (Weisenfeld 2018, pp. 272-78); on the cultural and religious clashes between Christianity and Conjure, see (Chireau 2003); for a look at the role of newspapers and the rise of Voodoo, see "Selling Voodoo in Migration Metropolises" (Cooper 2017, pp. 49-54).

11 Vodou and Voodoo: while these terms are often conflated in public discourses, they hold very distinct meanings. The former term denotes a cluster of sacred lineages associated with the worship of African and indigenous spirits in Haiti, while the latter is a contrived utility noun that reconstitutes race and religion as the projection of the Other. Also, the concept of "Voodoo" authorizes the dualism between magic and religion consistently applied in western classifications of indigenous and African systems of knowledge. A discussion that qualifies the historical distinction between these terms is (McGee 2012). 
grass skirts, feathered headdresses, ornamental necklaces, bones, and fetishes - registered the stereotype of the timeless "Native". (Figure 4) While 19th-century political cartoons and illustrated journals employed similar visuals in portrayals of indigenous people, Africana religions in 20th century comics were refracted through a prism of broadly pejorative tropes that belied their meaning as authentic spiritual traditions. Weighed against western standards and Anglo-Christian exceptionalism, African cultures were belittled; Africans were seen as abject denizens of the "dark continent", degenerate, lacking moral virtue, "without God, law, religion, or commonwealth". Defamation of African peoples in written and visual discourses would be used to rationalize the West's role in the slave trade, colonialism, and its postulations of scientific theories of white racial superiority. These accepted images of Africa and Africans filtered into the comics. Later, as 20th century European neo-colonial incursions into Africa ensued, the US, driven by imperialist competition, expanded its interests into adventures closer to home with the 1915 invasion of Haiti. As the living repository of Africana sacred traditions in the western hemisphere, Haiti would come to play a vital role in comics' representations of black religions. ${ }^{12}$

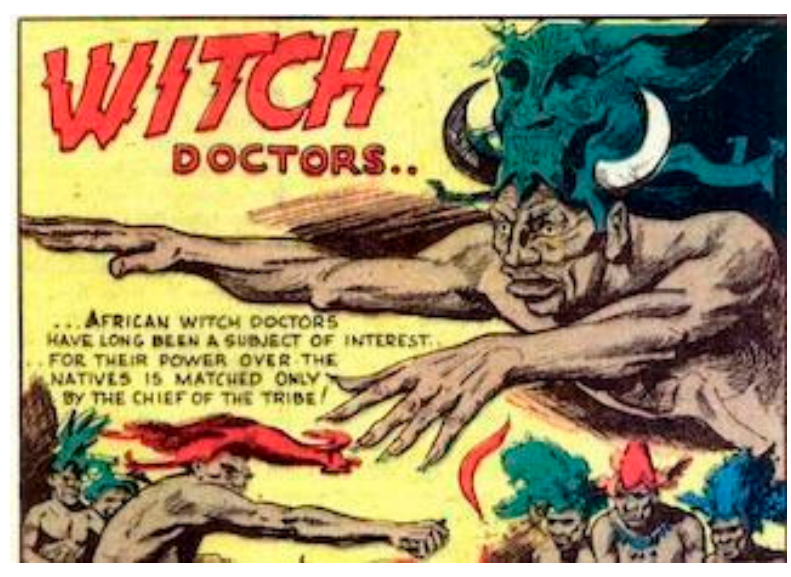

Figure 4. African Witch Doctors. Spellbound, 1954.

Depression-era newspaper strips were precursors to the anthologies and serials that transformed comics into comic books, becoming some of the most profitable print products in the US during the decades between 1938 and 1953. In comics of this period, black spirituality was still constituted as primitive, but presented as less of a laughing matter than with the earlier cartoons. Consider newspaper comics' introduction of Africana subjects in storytelling through the lenses of colonial and imperial mythologies, such as the renowned Tarzan strips and their competitors, Jungle Jim and The Phantom. As comics publishers capitalized on readers' desires for escapist literature, they delivered stores with a more potent combination of racial and religious images in exciting and dangerous forms. Graphic Voodoo served to vitalize the explosive growth enjoyed by jungle comic book brands during the World War II and postwar periods. With patriotic messaging and wartime propaganda, these comics embellished American national identity with "whiteness" as the cultural norm, while "blackness" and "Africanness" were marginalized and diminished, along with their religious subjects. Accordingly, jungle comics adopted the emerging conventions of the comic book form, with heroes and superheroes as purveyors of justice, action sequences that engaged the essential struggle between good and evil, and tropical/forest settings that symbolized the untamed wilderness. The black Voodoo priest personified the criminal element, the dark-skinned savage whose depravity was ever confronted

12 On the social and cultural impact of the Occupation, see (Renda 2001). 
and subdued by muscular white protagonists with greater intelligence, physical power, and athletic prowess. (Figure 5). ${ }^{13}$

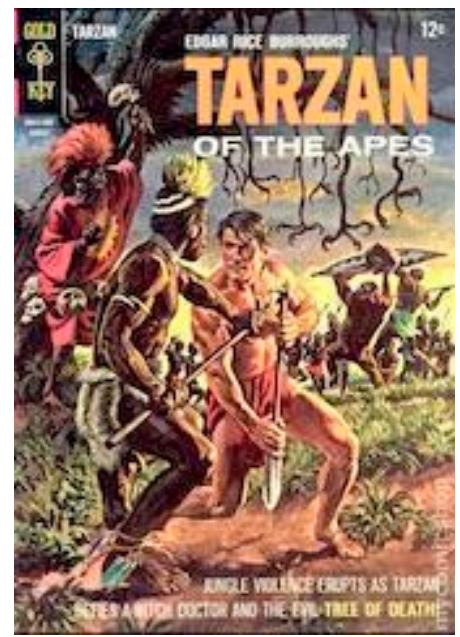

Figure 5. Voodoo Doctor from Tarzan comic book, 1965.

Although at least one African character, Waku: Prince of the Bantu, made his debut in the post-World War II era, most jungle adventure comics headlined white heroes and heroines, with blacks fulfilling secondary parts as foes and adversaries. ${ }^{14}$ For instance, the Fox syndicated comic book series Weird Comics (1940) introduced an antagonist called The Voodoo Man, an evil mastermind whose vengeful schemes against government agents, missionary doctors, and other innocents ignited a maelstrom of deceit, fraud, and greed that compounded the collective misfortunes of his African tribesmen (Figure 6). Although the Voodoo Man was one of the earliest comics to feature a black character in a recurring series, Voodoo criminals were as ubiquitous as the white jungle comics kings and queens whose stories they populated. The Voodoo comics nemesis also granted implicit justification for the mollifying presence of Christianity as a civilizing force, while giving voice to a regressive political discourse of black incapacity; left to their own devices, blacks were unsuited for self-governance, requiring rescue or protection from wild beasts, natural perils, unscrupulous whites, and cynical religious frauds whose sole intent was to beguile the gullible masses with false gods and heathen idols. The Voodoo priest enacted immorality and corruption, threatened vengeance and retribution toward all who opposed him, and validated a social message of white paternalism and American-Christian virtue on behalf of the heroic jungle monarchs. For its part, graphic Voodoo provided staging for assertions of black duplicity that were articulated in episodes of some of the most widely read superhero comics in the WWII period, including Superman, Detective Comics, Captain Marvel, and Captain America.

Perhaps even more detrimental to black religions in 20th century comics was the onset of horror fiction, which transformed graphic Voodoo from a formulaic plot device into grotesque allegories of ecstatic and violent black power. Repurposing fantasies of jungle primitivism into reflexive narratives of white terror, horror comics evinced a wellspring of suspense, the perversion of good into evil, and the recasting of Africana religions as diabolical in nature. Buoyed by the success of supernatural and fantasy articles in pulp magazines of the 1920s, Voodoo horror comics drew assiduously from published reports by foreign journalists, wartime commentators, and American servicemen in Haiti during this period (Figure 7). Men's popular magazines such as Weird Tales, Strange Tales, and Argosy

13 On the black comics hero form as cultural fiction, see (Brown 1999, pp. 27-28).

14 One of the first African American jungle comics characters, Lion Man, appeared in a leading role in the single issue of the black comics publication All-Negro Comics, in 1947. The popularity of graphic Voodoo themes also brought about the casting of white lead characters with names such as Doctor Voodoo, Voodah, and Vuda. See (Savage 1990, pp. 74-77). On the black Voodoo priest in the comics see (Jones 2016). 
refashioned the literature of the military occupation into fantastic and morbid drama for leisure readers of pulp fiction. The narratives ascribed a kind of supernatural fanaticism to devotees of Haitian Vodou, while projecting dark impulses and delusions of race and religion onto a poor, defiant black peasant population. The 20th century US intervention in Haiti and the persecution of Vodou evoked recollections of Haiti's extraordinary colonial history, its claims to nationhood, and the unthinkable possibility of black rule. The Occupation highlighted in palpable terms the limits of white Christian supremacy and American sovereignty, thereby expediting the need for racial and religious fictions that referenced Haiti as the site of the West's own lurking, hidden spiritual fears. ${ }^{15}$

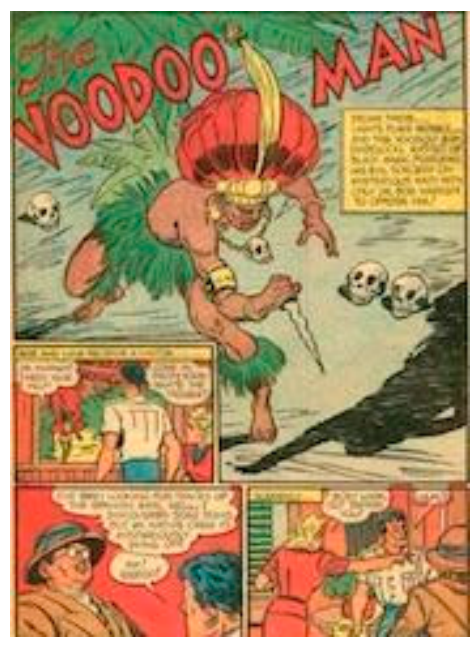

Figure 6. Early Black comic book villain, The Voodoo Man, 1940.

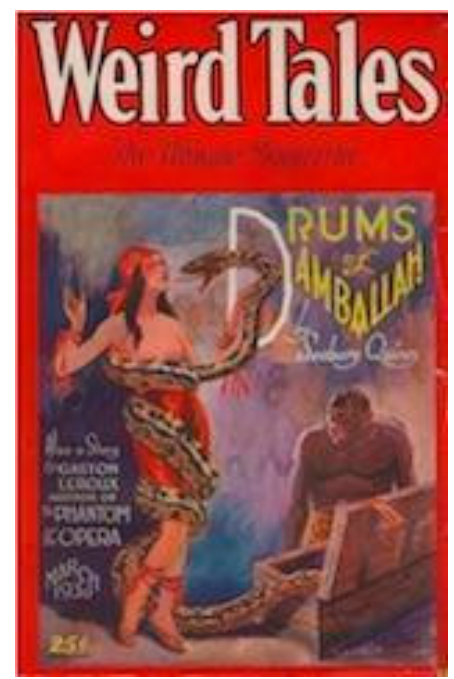

Figure 7. Voodoo-inspired cover on pulp magazine, 1940.

Although figurations of Voodoo had circulated in books, theater, and American film since the 1930s, graphic horror Voodoo was not extensively propagated until the World War II era, when a predominantly adult male comics readership developed a taste for more explicitly violent materials.

15 On the uses of Haitian Vodou in early 20th century American culture, see (Renda 2001); On Voodoo as a theme in early film, see (Coleman 2011) and (Senn 1998). With the transfiguration of Africana spirituality into horror Voodoo, we also see a shift from comics tropes, from a focus on the self-serving fetish priest to sinister spiritual perils that further detached Voodoo from its liberating origins, culminating with the non-person of the zombie, the abject living-dead slave. see (Cussans 2017), on the cultural uses of terror and Voodoo as Haitian Vodou horror. 
However, unlike jungle adventure comics, horror Voodoo framed Africana spirituality as the locus of malevolence, with images and stories of demonic possession, corporeal desecration, and diabolical violence. By the early 1950s, horror comic books such as Vault of Horror (1950), Black Magic (1950), Mysterious Adventures (1951), Phantom Witch Doctor (1952), and the Entertaining Comics series Voodoo had inverted the mythos of the white jungle king into allegories of white terror and black subjugation that transmuted actual wartime atrocities and abuses by American occupying forces into unbridled aggression toward the black Other (Figure 8). Voodoo-themed comic books also underscored Haiti's backwardness and instability, and reconfigured religious Vodou into graphic horror Voodoo. ${ }^{16}$ As author John Cussans has noted, the real-life suppression of Vodou in Haiti during the Occupation coincided with the government's attempt to win social and political support for American ambitions on the island. "Black practices of animal sacrifice, sorcery, cannibalism, ancestor worship, divination, zombification, and possession," he writes, "whether imagined or actual, served as a moral justification for an American civilizing mission that seemed to symbolically mark the end of the Haitian revolutionary experiment." The Voodoo comics, with all their horrifying excesses, functioned as an archive of lurid fantasies of black supernaturalism, which served both to legitimate American interests and provide a rationale for the continued denigration of Africana religious practices and beliefs. As standard comics fare for decades to come, graphic Voodoo perpetuated many of the lingering, distorted views of Africana religions that persist in popular culture even in the present day. ${ }^{17}$

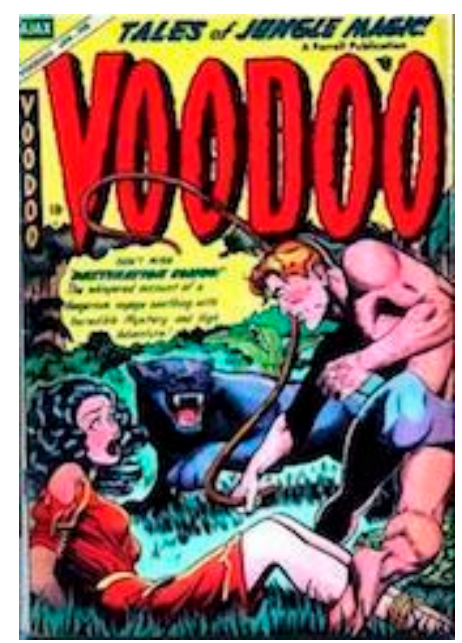

Figure 8. White jungle king tropes. Voodoo Comics, 1955.

With the imposition of a self-regulatory code of content for comics publishers in 1954, the remainder of the decade saw a decline in subject matter deemed morally offensive or overly controversial, including many religious, racial, and horror-themed materials. Despite the fact that, in the first half of the 20th century, both jungle adventure and horror comics reinforced notions of black spiritual primitivism, their entertainment value in the US was unparalleled. Since the 1930s, literary and theatrical works with Voodoo themes had been marketed to American audiences, culminating in what Melissa Cooper calls the "Voodoo craze", a cultural phenomenon in which Voodoo themes were utilized as consumable sources for news and entertainment. She notes that African American newspapers were active domains for the "mass commercialization and commodification" of Voodoo, with black journalists and black newspapers such as the Chicago Defender, the New York Amsterdam News, and the Pittsburgh

16 Such as the remarkable comic of the story of Faustin Wirkus, the "white king” of La Gonave, "(Gauvreau 1946).

17 (Cussans 2017). As sacred ground for African cultures and site of the only successful anti-slavery revolution in the West, Haiti was viewed as a powerful emblem of black resistance and freedom in black Atlantic. These themes were celebrated by pan Africanists and black nationalists as mythic sources of race pride the world over. See (Corbould 2011). 
Courier disseminating stories of Voodoo-related criminal activity and sponsoring advertisements for Hoodoo-Conjure services in their pages. Interestingly, the circulation of sensational Voodoo subjects by American media coincided with the events of the Occupation and its brutal repression of black resistance in Haiti. Yet, as many blacks in the US looked to the founding history of Haiti as a template for African American greatness, portrayals of Africana religions colored by the racist imaginary issued forth in a variety of forms. While black newspapers were of the few arenas in which African American points of view were advanced with an eye toward supplying greater substance, balance, and nuance to their readers, they too, notes Cooper, contained "a contradictory mix of voodoo coverage" that "condemned backwardness and superstitions in the black community" while covering "sensational voodoo reports designed to entice readers." Nevertheless, we see that it was in their emerging roles as social critics, political commentators, and humorists that African American newspaper writers and comics artists would provide new possibilities for thinking about and representing black religions in their totality. ${ }^{18}$

\section{Representation from the Inside}

We now turn to representations of black religion by African American writers, artists, and other comics creators in the 20th century. By the 1930s, the combination of an emerging consumer class and the expansion of black newspapers created a demand for more relatable themes for the reading public. Artists and illustrators sought syndication for their cartoons and comics in order to bring a greater variety of perspectives to their depiction of black subjects and to counter degrading imagery that appeared in the mainstream press. Black comics in the first half of the 20th century developed in concert with the independent black press, and the historical contributions of African American editorial cartoonists to the development of the form should not be underestimated. "Black cartoonists," writes cartoon historian Tim Jackson, committed to rebutting racist imagery of black people, and took "emphatic control of their self-image." Here, we see the ways that African American comics artists also issued positive representations of black religiosity that counterbalanced many of the images that circulated in American popular culture. Twentieth century black newspaper cartoon and comics artists drew upon what Angela Nelson calls a "black repertoire" in their depiction of religious characters and scenarios, articulating the political, ideological, and aspirational values of their readers (Figure 9). ${ }^{19}$

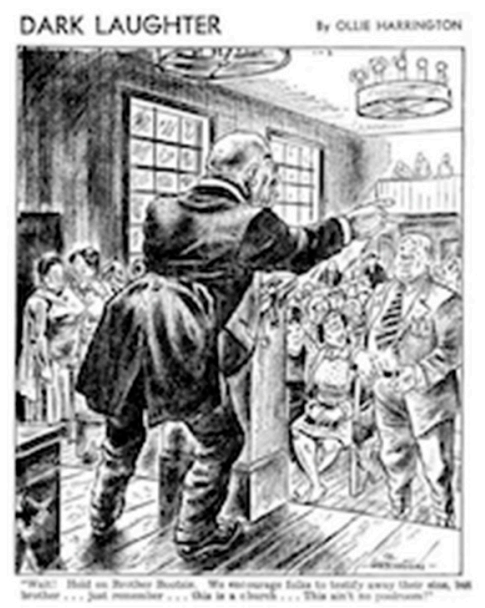

Figure 9. Black preacher as seen in newspaper comic strip. Dark Laughter, 1947.

18 (Cooper 2017); (Corbould 2011).

19 (Jackson 2016, p. 8); (Suggs 1983); (Gordon 1998). 
One unusual newspaper comic in this era that centered on black religiosity and the black church was Deacon Jones by Ike "Sam" P. Reynolds, columnist and local scribe of black Atlanta in the 1930s. Deacon Jones was published in the Atlanta Daily World from 1931-1932. Reynolds was well known for his reporting of local neighborhood happenings in and around the Auburn Avenue district, the thriving epicenter of black business and home to the renowned Ebenezer Baptist Church, an anchor of the African American religious community. Reynolds, who also wrote a gossip column called "Sam on the Avenue", instilled the homiletic voice and humor of the traditional black preacher into his comic, with sketches and inside jokes from the pulpit directed at the portly Deacon, whose witty and sometimes profane commentaries appeared daily in the newspaper with a single panel gag strip, and with a longer cartoon on Sunday. ${ }^{20}$

As rare as Deacon Jones was as a religion-themed newspaper comic strip, the appearance of black women in 20th century comics with religion topics was even more uncommon. Their absence may be attributed to the insidiousness of racialized gender stereotypes, an overemphasis on renditions of masculinity in comics, and the lengthy, troubling history of black women's exploitation with sexually objectifying images. Nevertheless, two comics serve as bookends to other examples in this arena: first, a four-page comics feature on the life of Sojourner Truth, which appeared in a 1945 issue of Wonder Woman called "Wonder Women of History". The product of an intersectional collaboration between the black artist Alfonso Greene and feminist icon Alice Marble, the short graphic biography depicts the abolitionist and preacher as a devoted slave mother, evangelical convert, and ardent women's rights advocate whose righteous dedication to her cause proved the "fighting spirit" she shared with other female subjects in the comic book series. In stark contrast, nearly 30 years later, the first syndicated newspaper strip with an African American female character in a title role debuted in the Chicago Tribune, a romantic soap opera called Friday Foster. The weekly comic, about the life, loves, and adventures of a single African American career girl, presented a limited story arc in which Friday, a photographer's assistant-turned-model, squared off against a "Hoodoo Doctor" gang kingpin and cult leader in the heady urban jungle of Harlem, New York. This episode repackaged graphic Voodoo themes with 1970s blaxploitation aesthetics and other period references. The Friday Foster newspaper comic strip enjoyed a four-year run and later took on a second life as a one-shot Dell comic book and a feature film before it was discontinued in 1975. Although these two publications present somewhat nominal portrayals of black religion, atypical as they were, their significance lies in their advancement of spaces for the future presence of black women in comics. ${ }^{21}$

Although religion remained a rock-solid institution in black American life, comics with a specific theological focus or spiritual orientation were hard to come by in the black secular press. Of course, black newspapers highlighted pertinent religious subjects, as with the signature works of the artist Ahmed Samuel Milai of the Pittsburgh Courier (1937-1950), whose cartoons for Your History and Facts about the Negro occasionally juxtaposed religious themes with notable persons of achievement from the annals of African American history (Figure 10). As comics became more deeply embedded within the fabric of American popular culture, black writers and artists over the decades strove to capture multiple dimensions of the African American experience by valorizing religious leaders and celebrities as exemplary figures and creating comic books and cartoon biographies of religiously significant personalities, such as Martin Luther King Jr., Muhammad Ali, and Malcolm X. African American religion was also presented in the comics as a catalyst for galvanizing nonviolent political activism, as seen in Martin Luther King and the Montgomery Story, a 1956 single issue comic book by the Fellowship of Reconciliation and published by the cartoon studio of Al Capp (of Lil Abner fame), which was distributed in schools and churches throughout the South. The 16-page comic also provided

20 (Jackson 2016); (Suggs 1983, pp. 135-36).

21 "Wonder Women of History: (Marble and Greene 1945); (Lawrence and Longaron 1973); Chicago Tribune-New York Syndicate (1970-1974). On black women and comics, see (Whaley 2016). 
inspiration for the 2015 award-winning graphic novel trilogy by Congressman John Lewis and Andrew Aydin, March. ${ }^{22}$

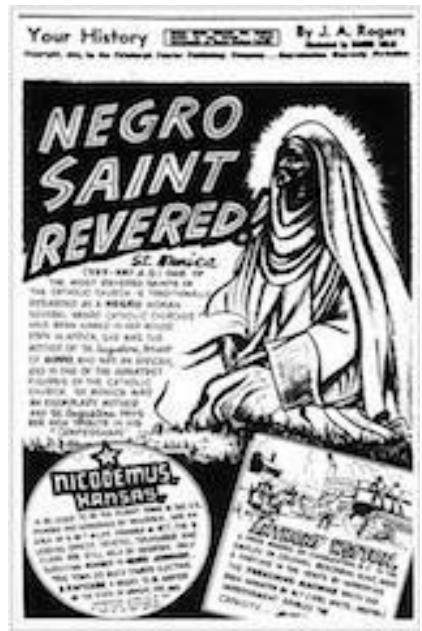

Figure 10. Sam Milai created comics for the syndicated feature Your History (1942).

While newspaper artists offered many meaningful contributions to the project of black representation, none treated religion more consistently than the illustrator Eugene Majied, editorial cartoonist for one of the most widely circulated African American newspaper weeklies in the 20th century, Muhammad Speaks. Majied, who began his career as an artist at the Chicago Defender in 1961, brought a sensibility to his work that instilled theological precepts from the Nation of Islam and foregrounded black Muslim religion in order to provide meaningful and positive self-images of African Americans. Moreover, while many of his cartoons were tempered with strong doses of racial political opinion, their subject matter dealt almost entirely with themes of religious uplift, black history, and matters of spiritual import that were infrequently addressed in secular newspaper comics. With incisive satire and penetrating analysis of current events, Majied's cartoons reflected his strongly held convictions on the redemptive teachings of Elijah Muhammad as they related to black self-reliance, racial discrimination in the United States, and economic empowerment. His comics appeared in Muhammad Speaks from 1960 to $1975 .{ }^{23}$

From the 1970s onward, black writers and artists harnessed the comics medium to support particular various theological agendas, to celebrate African American faith traditions, and to reinterpret traditional religious beliefs in light of a shared cultural heritage. One of the most prolific black comics illustrators from this period was the African American artist Fred Carter, whose work delivered a fundamentalist message of conservative Christian doctrine in an array of widely read pamphlets, tracts, and comic books by the Jack T. Chick Publications Company. Carter, an uncredited artist for the California-based publisher from 1975 to 1980, was known for his vivid oil-paint images which dramatized the horrors of sin, the judgment of the wicked, and the glory of spiritual conversion with distinctive graphics and lavish colors. His notable works for the Jack Chick studio included "Soul Story" and "The Sissy", and the Christian hero-duo series "The Crusaders." While illustrating numerous publications for the Jack Chick studio, Carter focused on creating content pertaining to African Americans and later redesigned Chick's persuasive missionary publications using only images of black people for tracts which focused on issues such as crime, drugs, abortion, and the presence of

22 (Benton and Barry 1958); (John Lewis and Powell 2013).

23 Another illustrious cartoonist for the Black Muslim newspaper was Abdelaziz Ramzah/Gerald 2X, creator of political cartoons in the 1960s and 70s. See (Jackson 2016, pp. 126-28); (Tisserand 2008). On African American Muslim characters in comics, see (Pruitt 2017). 
competing religions like Islam and African diaspora traditions. A Pentecostal minister, Carter also illustrated a race-specific bible for Nia Publishing/Urban Spirit Ministries called The Children of Color Bible, in which he reworked Old and New Testament stories into brightly rendered images of blackand brown-skinned characters with the original biblical narratives. ${ }^{24}$

In contrast with the prolific but sometimes controversial work of Jack Chick, other religious comics publishers made black representational inroads by adding storylines that were attuned to African American experiences. An example of this genre is the comic book Up from Harlem from Spire, an imprint of the Christian publisher Fleming H. Revell (1974), a company dedicated to creating educational comics with an evangelical theological slant. Up from Harlem is an account of the life story of the African American street-gang member turned preacher Tom Skinner, whose stirring biography was one of several titles published in Spire's extensive series of illustrated stories about celebrity Christians, ministers, and missionaries. The comic, which adopted the unmistakable idioms of the "Soul" era, relayed a dramatic account of Skinner's unlikely religious conversion and rescue from the social ills of poverty and inner-city gangs. Skinner, depicted in the comic as a real-life black "street prophet", would go on to become a charismatic motivational preacher whose passionate witness and radical critique of social and racial injustice made him one of the most prominent African American Christians on the white evangelical crusade and missionary circuit in the 1970s. Up from Harlem is one in a genre of publications that privileged the Christian viewpoint while focusing on the pathologies of urban African American culture, promoting the need for spiritual transformation among black people as a primary evangelical endeavor. ${ }^{25}$

In the final quarter of the 20th century, dedicated artists and writers adapted the modern conventions of comics storytelling in works that accorded complex characterizations of black religion in narratives of fantastic, superhuman characters and godlike heroes that spoke explicitly to themes of Africana spirituality and racial identity. With the introduction of African and African American superhero characters in mainstream comic books in the late 1960s, graphic Voodoo would be deployed once again, but now with an alternative, positive take on race and religion. A Marvel superhero by the name of Brother Voodoo first appeared in the 1973 comics series Strange Tales in a supporting role as a supernatural agent and protector of justice. Later, he would be featured in his own series as one of a leading generation of "black power" superheroes (Figure 11). Brother Voodoo personified conventional styles of superhero masculinity and enacted comics horror tropes while complicating questions of racial and religious authenticity in his role as an Africana religions practitioner. This time, it was Vodou, not Voodoo, that was reformulated as a weapon of choice in an arsenal of enhanced abilities for Jericho Drumm, a repatriated Haitian, in his secret identity as a mild-mannered and rational black psychologist. Brother Voodoo wielded a cache of superpowers loosely associated with Haitian Vodou, including the deities known as loa, the ritual technology of spirit possession, and the artifacts of magical protection and defense called wanga. Although the character engaged in supernatural warfare against zombies, evil bokors, demons, and stock graphic Voodoo villains, the comic drew from an extensive lexicon of Africana cultural styles that transformed him from a mystical sorcerer with an obscure pedigree into a consummate down-to-earth action hero with a historical black diasporic religious lineage. ${ }^{26}$

The 1980s and 90s inaugurated shifts in the work of comics writers and artists of the post-civil rights, post-black power generations, and institutionalized a more diverse readership of the comics themselves. A decisive period in mainstream comics production, unstable economic trends, and the declining sales of newsstand comic books led to an increase in direct marketing and a subsequent turn by artists and writers to more mature, violent, and psychologically driven narratives. Concurrent with these trends, the establishment of independent black comics had a massive impact on the medium

\footnotetext{
(Kuersteiner 2004).

On the life and career of Tom Skinner, see (Gilbreath 1996).

(Wein et al. 1973); (Nama 2011, pp. 105-10).
} 
itself, leading to a re-envisioning of black representation, with respect to themes of race, religion, and spirituality. A signal event was the 1993 founding of Milestone Media, a publishing collective of African American artists and writers that tapped crossover markets in an appeal to diverse audiences all the while initiating conversations about racial representation went beyond the black/white binary. ${ }^{27}$ Yet, while Milestone opened up opportunities for the presence of new black characters and themes, neither religion nor spirituality was of great significance to their conceptualizing of African American subjects. Milestone's culminating success was their achievement of greater ethnic representation in the comics industry and the recognition of the need for black comics creators to control the licensing, distribution, and publication of their products; it fell to independent black comics publishers, drawing impetus from cultural movements such as Afrocentrism and black nationalism, to put forth relevant religious subject matter. For instance, Onli Studios, founded by Chicago-based artist Turtel Onli, as well as the Association of Black Comic Book Publishers (also known as ANIA), a consortium of four Black-owned comic companies, promoted comics that merged ancient myths, black diaspora imagery, and Afrocentric themes with conventional crime and superhero narratives. In most of these comic books, spiritual, esoteric, and mystical symbols and themes formed the center of their vision of black culture. Insofar as these contemporary writers and artists considered mythic blackness and the Sacred as dual lenses with which to create stories and images, they utilized a variety of resources, including iconographic imagery derived from Egyptian and Khemetic motifs, technologically complex tropes from science fiction, and traditional theological frameworks from indigenous African faiths. Onli, also known as the father of the "Black Age of Comics", wrote, illustrated, and published a spectacular universe of comic book titles that employed black and Africana spiritual frameworks. Onli said that an "African American aesthetic" imbued his work with purpose and meaning as it drew inspiration from African American arts activism of the 1970s (in movements such as BAM). His spiritual and artistic sensibilities converged in the publication of his 1981 comic NOG, Protector of the Pyramides, the story of a powerful entity from a race of immortal beings whose mission was revealed to be cosmic guardian of the planetary outpost Nuba (Nubia). Similar themes would be taken up by other independent black comics in the latter decades of the twentieth century, including, notably, the work of Roger Barnes, whose Heru, Son of Ausar (1993) brought ancient stories of the Nile Valley to life in tales of primal beings, demigods, and goddesses that waged epic battles against earthly oppressors, presenting new mythologies of powerful black heroic defenders of the righteous against corrupt invaders and alien malefactors (Figure 12). ${ }^{28}$

By creatively adopting African-centered metaphysics and cosmologies in their world-making practices, latter twentieth century black comic writers and illustrators anticipated the black arts and culture movement known as Afrofuturism. In emphasizing the speculative and the technological in service to Africana identity and liberation, Afrofuturism re-envisions the past in ways that reach beyond the present histories of black people in the West. ${ }^{29}$ Comics Afrofuturism, as defined by communications scholar Reynaldo Anderson, is an aesthetic orientation that conceives of alternate realities, utopian and dystopian scenarios, and scientific archetypes in imagined narratives of the future for black people. Strongly mythic in its expressions, Afrofuturism "reinvents a visionary discourse related to the diasporic experience [that is] impacted by technological transformation," Anderson writes, but "remains connected to an African humanistic past." ${ }^{\prime 30}$ Religiously inspired Afrofuturism, in various manifestations, draws from indigenous African religions, biblical prophecy, and ancient esoteric literature as resources to explore topics like time travel, astronomy, space exploration, and the

27 (Dallas 2018, pp. 107-8); (Brown 2001).

28 (Womack 2013).

29 Afrofuturism emerged as a category of speculative narrative and art that combines science, blackness, technology, and culture. See (Womack 2013).

30 Reynaldo Anderson, "Critical Afrofuturism: A Case Study in Visual Rhetoric, Sequential Art, and Post-apocalyptic Black Identity", in (Gateward and Jennings 2015, pp. 182-83); (Womack 2013, pp. 142-45). 
integration of machine and human consciousness, centering characters and themes that speak to black resistance and liberation. By reformulating the mythic past and reconstructing the present through speculative narratives, independent black comics creators extended the very notion of "religion" beyond traditional conceptualizations and reclaimed Africana spiritual sources as central to the representation of black religions in US popular culture.

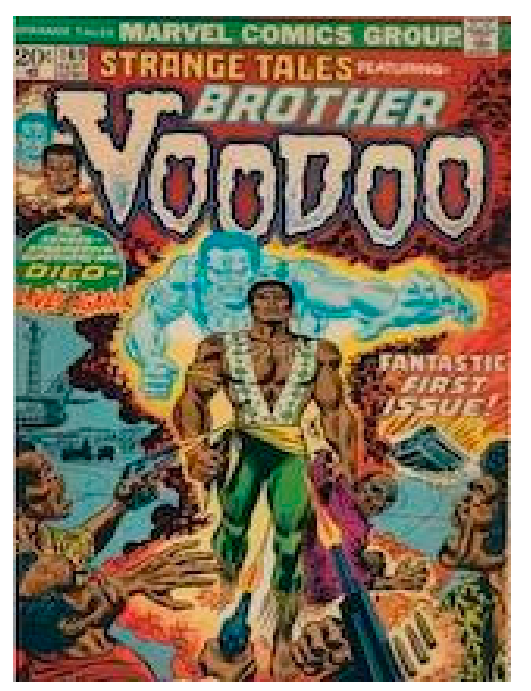

Figure 11. First cover appearance of Brother Voodoo, 1973.

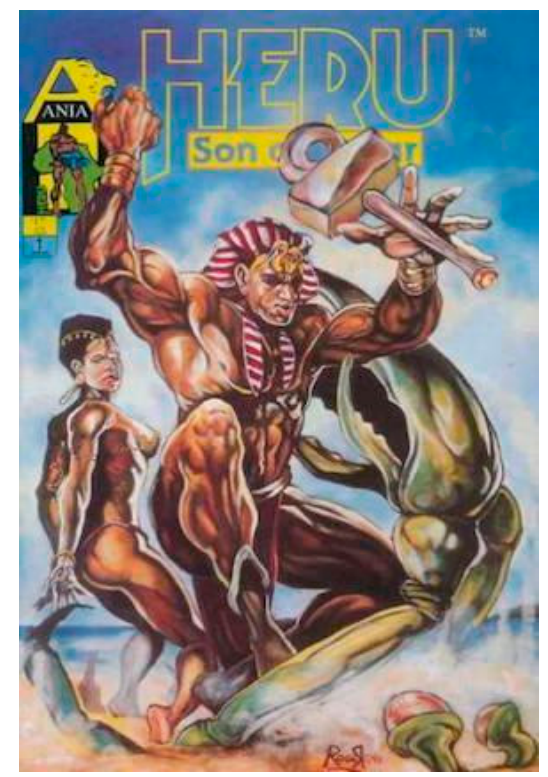

Figure 12. Sacred legends in Heru Son of Ausar. Afrocentric Comics, 1993.

\section{Conclusions}

We complete this discussion having come full circle, "looking at the past to retrieve what was lost, and reclaiming the present", as the wisdom sayings of the Akan Sankofa philosophers affirm. From early images of black religion in twentieth century comics to the present day-with the extraordinary 2018 comic book-based film Black Panther opening up new domains of Afrofuturist representation-black American religions and Africana spiritualities were transformed from a waning trajectory of negative images, stereotypes, and distortions that once dominated comics art and narrative. Even now, black and Africana spiritual themes resonate with the latest generation of comics consumers, whose relationship 
to race and religion appears to be far less sectarian and more religiously expansive than any that came before them. The comics of the past century offer an array of valuable lessons as we consider the treatment of black religion as subject matter in US popular culture. Comic books, cartoons, animation, and newspaper strips conveyed harmful assumptions and racist ideas in their treatment of black and Africana religions, but comics were also used as a corrective, offering truer and more authentic perspectives. This investigation of black religion and comics, while limited, shows how comics articulated understandings of blackness, race, and Africana spiritualities that both supported and contested the views of the dominant society. What conclusions may be drawn regarding the significance of black religions and their depiction in comics? Firstly, it is worth underscoring that, as the comic developed as a multi-faceted form in the twentieth century, so did the breadth of styles by which black religion was illustrated. From the early caricature and satirizing of African American church performances, black folk traditions, and Africana practices in cartoons and animation, to the contrasting presentation of religious themes as viable subject material by the black press and mainstream comic books, depictions of black religion were shaped by perceptions of their creators and their readers, even as the expansion of the comics medium would be ultimately industry-defined. The rise of Graphic Voodoo in the early twentieth century as an imaginary construction and false depiction of black religious and spiritual otherness is an example of the power of outsider representations that has had considerable cultural impact, as it was later adopted, appropriated, and disseminated both by insiders and others, becoming embedded within comics discourses even in the present day. Notwithstanding their commercialized aspects, comics centering on blackness and spirituality advanced over the decades as increasingly visible presentations of racial identity, becoming more salient in US popular culture. In response to these trends, black artists, writers, and creators in particular have developed more elaborate, complex, and authentic depictions of black religiosity and spirituality through comics storylines, characters, and images. It may be possible to consider comics as one of many forms of religious definition and expression - as facilitating new and imaginative spiritual practices of meaning-making through narrative, art, and social commentary that focus on traditional and non-traditional spiritual sources, persons, and subjects. Historically, black religious representation in comics originated as one-sided, created and offered as a spectacle to be viewed from the outside, looking in; in large part, the work of black artists and writers in the 20th century exemplified the struggle to correct and take control of the same so as to provide images and narratives with an insider's vision. It remains to be seen in what new directions comics and black religions will flow in as they extend into the 21st century, but it is clear that, for comics creators and their readers, the future is present.

Funding: This research received no external funding.

Conflicts of Interest: The author declares no conflict of interest.

\section{References}

Alexander, Torin Dru. 2018. Africana Religion, Black Panther, and the Marvel Cinematic Universe (MCU). Journal of Pan African Studies 11: 64-67.

Benton, Reswick, and Sy Barry. 1958. Martin Luther King, Jr. and the Montgomery Story (comic). Nyack: Fellowship of Reconciliation Press.

Brown, Marc. 1999. Comic Book Masculinity and the New Black Superhero. African American Review 33: 27-28.

Brown, Jeffrey A. 2001. Black Superheroes, Milestone Comics, and Their Fans. Jackson: University Press of Mississippi.

Chireau, Yvonne. 2003. Black Magic: African American Religions and the Conjuring Tradition. Berkeley: University of California Press, pp. 121-49.

Coleman, Robin Means. 2011. Horror Noire, Blacks in American Horror Films from the 1890s to Present. New York: Routledge Press, pp. 58-63.

Cooper, Melissa. 2017. Making Gullah: A History of Sapelo Islanders, Race, and the American Imagination. Chapel Hill: University of North Carolina Press, pp. 40-67. 
Corbould, Clare. 2011. At the Feet of Dessalines: Performing Haiti's Revolution during the New Negro Renaissance. In Beyond Blackface: African Americans and the Creation of American Popular Culture, 1890-1930. Edited by W. Fitzhugh Brundage. Chapel Hill: University of North Carolina Press, pp. 259-88.

Cowan, Denys. 1988. A Hero No More! Black Panther \#1, New York: Marvel Comics, July 1.

Curtis, Edward, and Danielle Sigler. 2009. New Black Gods: Arthur Huff Fauset and the Study of African American Religions. Bloomington: Indiana University Press, pp. 1-12.

Cussans, John. 2017. Undead Uprising: Haiti, Horror and the Zombie Complex. London: Strange Attractor Press, pp. 85-86.

Cutter, Martha. 2017. The Illustrated Slave: Empathy, Graphic Narrative, and the Visual Culture of the Transatlantic Abolition Movement. Athens: University of Georgia Press.

Dallas, Keith. 2018. American Comic Book Chronicles: The 1990s. Raleigh: Two Morrows Publishing, pp. 107-8.

Faithful, George. 2018. Dark of the World Shine on Us: The Redemption of Blackness in Ryan Coogler's Black Panther. Religions 9: 304. [CrossRef]

Finley, Stephen, and Margarita Guillory. 2015. Esotericism in African American Religious Experience. Boston: Brill Publishing, pp. 71-85.

Gateward, Frances, and John Jennings. 2015. The Blacker the Ink: Constructions of Black Identity in Comics and Sequential Art. New Brunswick: Rutgers University Press.

Gauvreau, Emile. 1946. Famous Marine Crowned King of the Voodoos. In Picture News Comics \#4. New York: Lafayette Street Corporation.

Gilbreath, Edward. 1996. A Prophet out of Harlem. Christianity Today 40: 36-43.

Gordon, Ian. 1998. Comic Strips and Consumer Culture, 1890-1945. Washington: Smithsonian Institution Press, pp. 59-79.

Hajdu, David. 2008. The Ten-Cent Plague: The Great Comic Book Scare and How it Changed America. London: Picador. Inge, M. Thomas. 1979. The Comics as Culture. Journal of Popular Culture 630. [CrossRef]

Jackson, Tim. 2016. Pioneering Cartoonists of Color. Jackson: University Press of Mississippi.

Jones, William. 2016. The Ex-Con, Voodoo Priest, Goddess, and the African King: A Social, Cultural, and Political Analysis of Four Black Comic Book Heroes. Philadelphia: CreateSpace Publishing, pp. 41-43.

Kuersteiner, Kurt. 2004. The Unofficial Guide to the Art of Jack T. Chick: Chick Tracts, Crusader Comics, and Battle Cry Newspapers. Atglen: Schiffer Publishing Co., pp. 7-8.

Lawrence, Jim, and Jorge Longaron. 1973. Friday Foster. Chicago Tribune. Chicago: Chicago Tribune Syndicate.

Lehman, Christopher. 2007. The Colored Cartoon: Black Animation in American Short Films, 1907-1954. Amherst: University of Massachusetts Press.

Lewis, C. David, and Christine Hoff Kraemer, eds. 2010. Graven Images: Religion in Comic Books and Graphic Novels. New York: Continuum Publishing Corporation.

Lewis, C. David, and Martin Lund. 2017. Muslim Superheroes: Comics, Islam, and Representation. Boston: Ilex Foundation.

John Lewis, Andrew Aydin, and Nate Powell. 2013. March. Marietta: Top Shelf Productions.

Love, Tirhakah. n.d. Black Panther's Spirituality Pulls from Reality. Available online: https://www.syfy.com/ syfywire/wakanda-wednesdays-black-panthers-spirituality-pulls-from-reality (accessed on 15 March 2019).

Marble, Alice, and Alfonso Greene. 1945. Wonder Woman of History: Sojourner Truth. Wonder Woman \#13. In National Comics. New York: Quality Comics.

McGee, Adam. 2012. Haitian Vodou and Voodoo: Imagined Religion and Popular Culture. In Studies in Religion/Sciences Religieuses. New York: SAGE Publishing, vol. 41, pp. 231-56.

Nama, Adilifu. 2011. Super Black: American Pop Culture and Black Superheroes. Austin: University of Texas Press.

Nelson, Angela. 2013. Studying Black Comic Strips: Popular Art and Discourses of Race. In Black Comics: The Politics of Race and Representation. Edited by Sheena Howard and Ronald Jackson. London: Bloomsbury Publishing, pp. 91-102.

Nyberg, Amy. 1998. Seal of Approval: The History of the Comics Code. Jackson: University Press of Mississippi.

Perez, Elizabeth. 2015. Working Roots and Conjuring Traditions: Relocating Black Sects and Cults in African American Religious History. In Esotericism in African American Religious Experience. Edited by Stephen Finley and Margarita Guillory. Leiden: Brill Publishers, pp. 71-85.

Pruitt, Dwain. 2017. The Comics that Hate Produced: Representing the African American Muslim Experience in the Comics. In Muslim Superheroes. Edited by David Lewis and Martin Lund. Boston: Ilex Foundation. 
Renda, Mary. 2001. Taking Haiti: Military Occupation and the Culture of US Imperialism. Chapel Hill: University of North Carolina Press, pp. 170-178.

Sammond, Nicholas. 2015. Birth of an Industry: Blackface Minstrelsy and the Rise of American Animation. Durham: Duke University Press Books.

Sampson, Henry T. 1998. That's Enough, Folks: Black Images in Animated Cartoons, 1900-1960. Lanham: Scarecrow Press, Inc.

Savage, William. 1990. Comic Books and America, 1945-1954. Norman: Univ of Oklahoma Pr.

Senn, Bryan. 1998. Drums O' Terror: Voodoo in the Cinema. Baltimore: Luminary Press, pp. 11-17.

Singer, Marc. 2002. Black Skins and White Masks: Comic Books and the Secret of Race. African American Review 36: 107-19. [CrossRef]

Stromberg, Fredrik. 2003. Black Images in the Comics: A Visual History. Seattle: Fantagraphics Books.

Suggs, Henry Lewis. 1983. The Black Press in the South, 1865-1979. Westport: Greenwood Press, pp. 135-36.

Taylor, Garland Martin. 2014. Out of Jest: The Art of Henry Jackson Lewis. Critical Inquiry 40: 198-202. [CrossRef] Tisserand, Michael. 2008. The Cartoonist and the Champ. The Comics Journal. Available online: http://www.tcj. com/the-cartoonist-and-the-champ/ (accessed on 21 June 2019).

Wein, Len, Gene Colan, and Dan Adkins. 1973. Brother Voodoo! Strange Tales \#169, New York: Marvel Comics.

Weisenfeld, Judith. 2018. New World A-Coming: Black Religion and Racial Identity During the Great Migration. New York: New York University Press, pp. 272-78.

Whaley, Deborah Elizabeth. 2016. Black Women in Sequence: Re-inking Comics, Graphic Novels, and Anime. Seattle: University of Washington Press, pp. 3-27.

White, Sylvia E., and Tania Fuentez. 1997. Analysis of Black Images in Comic Strips, 1915-1995. Newspaper Research Journal 18: 72-85. [CrossRef]

Womack, Ytasha. 2013. Afrofuturism: The World of Black Sci-Fi and Fantasy Culture. Chicago: Chicago Review Press, pp. 142-45.

(C) 2019 by the author. Licensee MDPI, Basel, Switzerland. This article is an open access article distributed under the terms and conditions of the Creative Commons Attribution (CC BY) license (http://creativecommons.org/licenses/by/4.0/). 